\title{
Effect of Organizational Structures and Types of Construction on Perceptions of Factors Contributing to Project Failure in Pakistan
}

\author{
UNEB GAZDER*, AND RAZA ALI KHAN* \\ RECEIVED ON 16.01.2016 ACCEPTED ON 29.05.2017 \\ ABSTRACT
}

\begin{abstract}
The construction industry is viewed as the regulator of national economy globally. Its importance in Pakistan has increased greatly because of the involvement of international funding agencies in infrastructure projects. The feasibility of such projects is largely dependent upon the satisfaction of multiple stakeholders. Hence, it is important to explore the factors considered by different construction organizations in evaluating the failure of their projects. This study focuses on providing a rating of factors affecting construction project failures in the construction industry of Karachi. In addition to that, difference in perception between professionals belonging to different construction projects and organizational structures has also been evaluated. The results of this study show that factors related to project planning and management are rated higher by professionals in general. Secondly, it was also observed that client satisfaction and its related factors were rated higher by organizations with projectbased management structures.
\end{abstract}

Key Words: Construction Projects, Failure, Perception, Organizational Structure.

\section{INTRODUCTION}

$\mathrm{T}$

The significance of the construction sector is now globally accepted and both developing and developed countries have realized the importance of the construction sector in sustainable growth in the economy.

Pakistan had also realized the significance of the construction sector in the early days of its independence and started to develop the sector. Presently it has become one of the important sectors of the country's economy. A huge investments are coming into this sector from foreign investors, including but not limited to, Malaysia, Singapore, China, UAE. Recently the foreign investors have committed to invest for US $\$ 43$ billion on two islands of Town Bin Qasim, US\$68 billion for a New City Project in Hawksbay, Karachi and are also constructing mega housing projects in Lahore, Gwadar, Manglaand DHA Karachi and Islamabad (http://www.buildasia.net/). The government of Pakistan is looking forward for local and international investors to build Mass Transit Systems in all big cities of Pakistan, and the network of roads,

Corresponding Author (E-Mail: alikhan.raza@gmail.com)

* Department of Civil Engineering, NED University of Engineering \& Technology, Karachi.

Mehran University Research Journal of Engineering \& Technology, Volume 37, No. 1, January, 2018 [p-ISSN: 0254-7821, e-ISSN: 2413-7219] 
highways and motorways all over the country on the basis of BOT, BOOT, PPP and BLT system. These large investments need to be justified from the perspective of all stakeholders. Hence, analysis of stakeholder perception becomes an important issue for the present times.

The construction sector is a unique sector of the economy, which is sharply different from the other sectors of the economy. It is complex, fragmented and highly sensitive to the business cycle, and socioeconomic and political environment [1]. It is a project based industry, which is required the successful coordination of all project parties to satisfactorily achieve the desired results [2]. It is observed that the rate of failure in construction business is significantly higher as compared to the failure rate in other businesses. There are many definitions of business or project failure, however, in construction business project failure means the expectations of the stakeholders in terms of cost, time and quality are not satisfied. The Project Management Institute [3] suggests that the success or failure of a project can be measured by taking the difference of what is expected from the project during and after its completion and the actual observed performance of the project when it is executed.

There are a number of research studies, conducted to investigate the causes, identification of factors and risky activities that could lead to project failure in construction business such as Schleifer [4] identifies ten risky activities divided into two group business strategies and fiscal group. Ogunlana and Vithool [5] identified three main categories of problems which have great influence on project performance as; inadequacies in industry infrastructure, clients and consultants difficulties, and the incompetency's of the contractors.
Russell and Jaselskis [6]developed a model for predicting variables of contractor failure prior to awarding contract. This study identified four most significant variables that could be considered as powerful predictors for contractor failure, Client-contractor evaluation, cost monitoring, the level of contractor supportand the early engagement of the project manager were researched as significant variables. A study conducted by Kazaz et. al. [7] in Turkey identified that the three most significant causes of projectfailure in construction industry were; design and material changes, delay of payments and cash flow difficulties by contractors. Jannadi's [8] study concluded that the most important factors of failure in construction business are "difficulties in hitting bids", "bad judgment", "inexperience in the company's line of business" and “poor cash flow management”. Arditi et. al. [9] highlighted that the strong control over budget and rapid response against economic conditions would reduce the probability of failure. Davidson and Maguire [10] indicated most common causes of construction contractor failure in the light of certified public accounts and sureties of failed construction companies are; (a) rapid growth, (b) obtaining contract in a new geographic region, (c) dramatic increase in size of job, (d) obtaining innovative types of work, (e) high employee turnover, (f) inappropriate capitalization, (g) poor estimation and crude accounting systems (h) poor cash flow management, and (i) buying dumb stuff. Kangari [11] also suggested in his study that the construction companies should not only consider the overall failure, but also keep the eyes on their success level in term of managing the estimated profit.

The above cited literature deals with the factors affecting construction project failure, in general, but does not deal with the differences in these factors in different construction sectors and organizations or perception of stakeholders in this regard. However, the factors affecting

Mehran University Research Journal of Engineering \& Technology, Volume 37, No. 1, January, 2018 [p-ISSN: 0254-7821, e-ISSN: 2413-7219] 
project success in different types of construction sectors and the effects of organizational/project management structure on it have been researched in isolation. The following sub-sections provide a brief overview of literature found in this area of research in other parts of the world.

\subsection{Factors Affecting Building Construction Projects}

Sanvido et. al. [12] investigated the factors that define project success for building projects in the Pennsylvania State, USA. They collected the data from 16 projects and validated their findings. The critical factors for project success were found to be related to project planning and communication.

Nguyen et. al. [13] conducted a study to analyze factors affecting project success in Vietnam. They acknowledged the complex nature of construction projects. They divided the success factors into 4 major categories; comfort, competence, commitment and communication. They concluded that the factors which were ranked higher by the professionals were all human related. They also claimed that the results of their study can be applied construction sectors of other Asian countries.

Doloi et. al. [14] conducted a study to investigate the factors affecting delays in the Indian construction industry. They identified 7 critical factors as the cause of delay, namely; lack of commitment; inefficient site management; poor site coordination; improper planning; lack of clarity in project scope; lack of communication; and substandard contract.

Yong and Mustaffa [15] carried out a study to investigate the factors affecting construction project success in Malaysia. They identified seven critical factors, all of which included human related factors. The main categories of these included competence, commitment, communication and cooperation.

\subsection{Factors Affecting Infrastructure Construction Projects}

The nature of infrastructure construction projects is different as compared to building projects. Ye and Tiong [16] stressed on the fact that infrastructure projects involve greater political, financial and market risks. Hence, a number of studies have focused exclusively on this particular sector of the construction industry.

Li et. al. [17] evaluated the critical success factors for Public-private partnerships and Private Finance Initiative. These two methods are commonly applied for infrastructure project financing.Their study was based in the UK. They were able to filter out the following factors as critical for infrastructure project success; 'a strong and good private consortium', 'appropriate risk allocation' and 'available financial market'.

In a similar study done by Zhang [18] critical factors were evaluated for UK infrastructure projects done through Public-private partnerships. The focus of their study was to find the difference in perception between the industry and academia with regards to success factors for infrastructure projects. They have concluded that generally, the perception about these factors is the same in both sectors.

Chou et. al. [19] analyzed and compared the critical success factor for High Speed Rail and general infrastructure projects in Taiwan. The projects done through public private partnerships were the focus of their study. They concluded that the success factors for high speed rail projects are the same as for general infrastructure projects, provided that the project delivery method is public private partnership.

Mehran University Research Journal of Engineering \& Technology, Volume 37, No. 1, January, 2018 [p-ISSN: 0254-7821, e-ISSN: 2413-7219] 
Li et. al. [20] pointed to the fact that it is essential to gain public acceptance for infrastructure projects to justify their costs. They also found that the success/failure of these projects is largely impacted by the perception difference among project stakeholders.

Hwang et. al. [21] determined the allocation of project risk factors for infrastructure projects involving public private partnerships. Their study area was Singapore in which this project delivery method has been commonly used for infrastructure projects. The important success contributing factors were found to be "well-organized public agency”, "appropriate risk allocation and sharing” and "strong private consortium".

\subsection{Effects of Organizational Structure on Project Failure}

Researchers have reported that organization structure also plays an important role in project failure/success irrespective of the type of business or project [22-25]. Hence, it should be considered as another avenue to be explored in investigating the project successes which have been done by a number of researchers.

Hyvari [22] investigated the effectiveness of different factors, including management structures on different business organizations. He concluded that organization design is directly linked with project management effectiveness. In another study, Hyvari [23] explored the link between critical project success factors and the organizational parameters. He concluded that the organization factor such as the size and structure of the organization changes the critical success factors for projects carried out by them.

Lechler and Dvir [24] explored the link between project management structure and project success. Their dataset comprised of 600 samples from US and Germany. They stated the fact that the link between project management structure and project success is independent of the type and size of the projects. Joslin and Muller [25] investigated the use of different project management methodologies and project success. Project management methodologies determine the management hierarchy and command structure of the project so it can be taken as a surrogate for organizational structure. They mentioned that these methodologies account for approximately 22\% of project success. They also concluded that projectbased methodologies prove to be more effective for project success as compared to other complementary methodologies.

\subsection{Need and Objectives of the Study}

The above literature identifies the following gaps in the current research horizon, (i) There is a lack of research on factors affecting construction project failure in Pakistan, (ii) There is a lack of research in investigating the perception of professionals involved in different types of construction projects regarding factors contributing to project failure, and (iii) Type of project and organization structure both affect perceptions about project success/ failure, in spite of this fact, there has been no study found which addresses these two areas simultaneously. The above points instigate the need of this research which would provide a step in the positive direction for the researchers of construction engineering.

Thepurpose of this study is to identify the factors contributing to project failure in Pakistan construction industry. This study aims to determine the perception of Pakistan's construction industry professionals regarding the factors contributing to project failures. In addition to that, it is also extended to find out the difference in perception between various nature of construction and organizational structures. The data for this study was collected from key professionals, including engineers, project and financial managers, of different construction

Mehran University Research Journal of Engineering \& Technology, Volume 37, No. 1, January, 2018 [p-ISSN: 0254-7821, e-ISSN: 2413-7219] 
organizations. This data was also partially used in the Khan et. al. [26]; however, the evaluation of perception was not part of the said study.

\section{MATERIALS AND METHOD}

The main goal of this study was to determine the factors affecting failure in Pakistan construction industry. Considering the diversified nature of industry practices, following objectives were set for this study (i) Rating of factors affecting project failure in construction industry and (ii) To study the effect of different organizational structure and construction sectors on the rating of the above factors.

Survey for this study was conducted through a questionnaire based interview which was distributed and collected from a number of industry professionals. All respondents have the minimum qualification of graduation. The survey respondents included personnel with a wide range of experience. The average value for the experience for the respondents was found to be 8.6 years. While the maximum and minimum values of this parameter were 41 and 1 year respectively.

The respondents' organizations can be categorized in two ways, namely; type of organization and type of construction projects carried out by the organization. There were mainly two types of organizations in the survey sample, i.e. functional and project based organization. Similarly, the types of construction projects were also divided into two categories; building construction and infrastructure projects. The distribution of the data samples was approximately 50-50 according to organization type as well as project type.

The survey was focused on determining the perception of the respondents regarding the factors contributing to project failure. These factors were identified from the literature and the respondents were asked to rank these factors, from 1-5 (1 = least impact, most impact), according to their impact on project failure. Based upon this ranking, average impact of each factor was calculated using Equation (1) [27]. The values of average impact factors, by both methods are given in Table 1 .

$$
\mathrm{WAI}=\sum_{\mathrm{i}=1}^{5} \mathrm{I}_{\mathrm{i}} \times \mathrm{P}
$$

Where WAI is Weighted Average Impact Factor, Iis Impact Rating (1-5), and P is Proportion of respondents choosing the specific impact rating.

Table 1 shows that the factors related to project planning and management have more impact on project failure. This includes; poor management decisions, insufficient project planning and lack of leadership. Another interesting fact is that the issues related to clients' needs and expectations are low on the impact rating. This may be due to the fact that this factor is dependent on other factors which were included in this study.

Before proceeding with further statistical analysis, it was important to establish whether the data satisfies the basic assumption that the WAI values follow a normal distribution. Application of t-statistic and correlation will not be valid if this requirement was not met. Hence, a frequency distribution curve was plotted for WAI values of the collected data using values for each individual. The plot is shown in Fig. 1 and the trend line on this plot confirms the fact that the WAI values follow a normal distribution.

\section{RESULTS AND DISCUSSION}

As mentioned above, that the perceptions of professionals were evaluated regarding the factors contributing to the project failure. A comparison was made between different types of projects and organizational 
structures. Two criteria were used in order to compare the perceptions, namely t-test and rank correlation (also known as the Spearman correlation coefficient). These parameters can be calculated using Equations (2-3).

$\mathrm{t}=\frac{\mu_{1}-\mu_{2}}{\sqrt{\frac{\mathrm{S}_{1}^{2}}{\mathrm{n}_{1}}+\frac{\mathrm{S}_{2}^{2}}{\mathrm{n}_{2}}}}$

$r_{g}=1 \frac{\sum d^{2}}{\left(n^{3}-n\right)}$

Where $\mathrm{t}$ is the standard student t-distribution, $\mu_{\mathrm{i}}$ represents the mean of two samples, $\mathrm{S}_{\mathrm{i}}$ represents the standard deviation of the samples [28]. In Equation (3), $r_{g}$ is the rank correlation coefficient, $d$ is the difference between the rankings of the two data sets and $n$ is the number of data pairs. T-test provides a parametric test related to equality of means for the two data sets. On

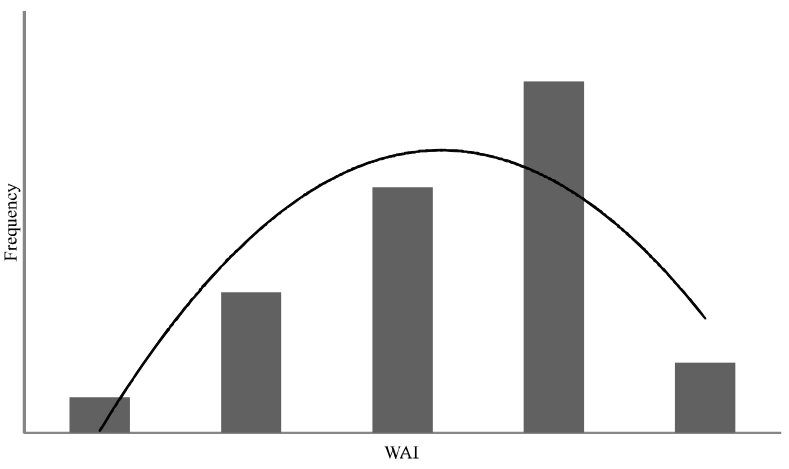

FIG. 1. FREQUENCY DISTRIBUTION CURVE

TABLE 1. AVERAGE IMPACT FACTORS

\begin{tabular}{|c|c|}
\hline Factor & Weighted Average Impact Factor \\
\hline Unsound Management decisions & 4.08 \\
\hline Poor planning Process for implementation & 3.85 \\
\hline Poor leadership & 3.82 \\
\hline Inaccurate evaluation of project time/duration & 3.78 \\
\hline Inadequate coordination and communication & 3.77 \\
\hline Impossible deadlines imposed on the project & 3.75 \\
\hline Poor Team management & 3.73 \\
\hline Key project stakeholders Conflict & 3.69 \\
\hline Inadequate project formulation & 3.63 \\
\hline Invalid budgeting process & 3.63 \\
\hline Failure to adequately distinguish, document and track requirements & 3.61 \\
\hline Lacking resources in term of financing and staff & 3.59 \\
\hline Centralized proactive management initiatives to take on project risk & 3.50 \\
\hline No change control process & 3.46 \\
\hline Enterprise management of budget resources & 3.46 \\
\hline Discrepant objectives and goals & 3.44 \\
\hline Changes in scope of work and location & 3.38 \\
\hline Lack of End user input & 3.38 \\
\hline Defined roles and responsibilities & 3.35 \\
\hline Poor procurement practices & 3.18 \\
\hline Inadequate financial methods & 3.18 \\
\hline Undefined requirements & 3.15 \\
\hline Changes in Organizational priorities & 3.12 \\
\hline Meeting Client expectations & 3.07 \\
\hline
\end{tabular}

Mehran University Research Journal of Engineering \& Technology, Volume 37, No. 1, January, 2018 [p-ISSN: 0254-7821, e-ISSN: 2413-7219] 
the other hand, rank correlation is a non-parametric testing procedure which shows the interdependence of the ranking between the observed datasets [29]. The proceeding sections present the results and discussion on these statistical analyses for this study.

\subsection{Comparison of Perceptions between Building and Infrastructure Projects}

Building construction is different in terms of its planning and financial management procedures as compared to infrastructure projects. The latter is carried out at a much larger scale and the social, economic and other relevant factors have to be taken into account. Hence the perception regarding failure of these projects may differ from one another. Table 2 presents the results of comparison of factors causing failure for these two types of projects. The comparison is made in terms of probability of t-statistics, calculated as per Equation (2), from standard t-distribution and the rank-correlation. As the probabilities for the t-statistic go higher, the chances of getting the same mean value for both data sets will increase, indicating that the difference in perception of the groups is becoming statistically insignificant. An Increase in the values of rank correlation shows the higher interdependence among rating datasets.

TABLE 2. COMPARISON OF BUILDING AND INFRASTRUCTURE PROJECTS

\begin{tabular}{|c|c|c|}
\hline Factor & t-test Probability & Rank Correlation \\
\hline Inadequate project formulation & 0.57 & 0.89 \\
\hline Poor planning process for implementation & 0.90 & 0.94 \\
\hline Discrepant objectives and goals & 0.22 & 0.84 \\
\hline Changes in scope of work and location & 0.81 & 0.87 \\
\hline Inaccurate evaluation of project time/duration & 0.26 & 0.84 \\
\hline Lacking resources in term of financing and staff & 0.38 & 0.89 \\
\hline Poor procurement practices & 0.14 & 0.90 \\
\hline Inadequate financial methods & 0.48 & 0.89 \\
\hline Invalid budgeting process & 0.87 & 0.87 \\
\hline Enterprise management of budget resources & 0.50 & 0.92 \\
\hline Poor leadership & 0.81 & 0.89 \\
\hline Changes in Organizational priorities & 0.20 & 0.79 \\
\hline No change control process & 0.41 & 0.89 \\
\hline Meeting Client expectations & 0.35 & 0.83 \\
\hline Centralized proactive management initiatives to take on project risk & 0.83 & 0.91 \\
\hline Failure to adequately distinguish, document and track requirements & 0.12 & 0.79 \\
\hline Poor team management & 0.50 & 0.82 \\
\hline Unsound management decisions & 0.74 & 0.87 \\
\hline Impossible deadlines imposed on the project & 0.15 & 0.87 \\
\hline Ill-defined roles and responsibilities & 0.80 & 0.87 \\
\hline Inadequate coordination and communication & 0.16 & 0.77 \\
\hline Key project stakeholders Conflict & 0.36 & 0.89 \\
\hline Lack of End user input & 0.92 & 0.90 \\
\hline Undefined requirements & 0.91 & 0.91 \\
\hline
\end{tabular}

Mehran University Research Journal of Engineering \& Technology, Volume 37, No. 1, January, 2018 [p-ISSN: 0254-7821, e-ISSN: 2413-7219] 
It can be observed from Table 2 that the difference between perceptions related to project communications is statistically more significant as compared to other factors. These factors include discrepant (varied/ conflicting) goals and objectives, inadequate documentation and communication practices. This indicates the fact that the importance of communication procedures is perceived differently for building and infrastructure projects in Pakistan. Another observation relates to the factors affected by organizational practices, such as organizational priorities and procurement practices, also seem to have statistically higher difference in perceptions. This can be attributed to that fact that infrastructure projects are carried out by organizations (mostly public) which have different structures as compared to other construction companies. Interestingly, there is a statistically higher difference in perception for factors related to evaluation of project durations. A possible explanation for this could be that infrastructure projects have longer project and procurement durations, so they are less sensitive to time as compared to smaller building projects. This is also confirmed by the WAI values of this factor which is higher (3.91) for building construction projects as compared to infrastructure construction projects (3.45). However, further research in this area is warranted.

The rank correlation coefficients are very close to unity for almost all the factors which shows that in spite of the difference in perception, the two datasets belong to the same distribution. However, factors related to organization practices (including procurement, communication and prioritization of resources) have comparatively lower interdependence than other factors. This observation reinforces the point that basic difference between perceptions of these two construction sectors is because of the change in their organization structure.

\subsection{Comparison of Perceptions between Functional and Project - Based Organizations}

Functional structure is most commonly found in the manufacturing and public sector organizations. Each division in these organizations is dedicated towards the responsibilities for their pertinent area of specialization. The interaction between them is only related to their contribution to the product, Rober et. al. [30]. Project based organizations, on the other hand, have become more popular in the construction as well as software development firms. These organizations work in the form of teams designated for each project which consist of experts from all relevant fields of the project. These teams are responsible for planning, designing and execution of the project and coordinate with each other from start to end of the project (Peltokorpi and Tsuyuki, 2006). Table 3 presents the results of t-test and rank correlation analysis for the functional and project based organizations related to their perceptions of factors causing project failure.

Table 3 shows that there is a vast difference in perception for "Meeting Client Expectations" factor between these organizations. This factor has the lowest values of ttest probability as well as a rank correlation coefficient. It was observed that project based organizations rate this factor higher (WAI $=3.58$ ) as compared to the functional organizations (WAI $=2.67$ ). This is understandable since project based organizations are more dedicated towards the project instead of their organizational activities, while it is the other way around in functional organizations. There was statistically higher difference in perceptions between these organizations for factors related to team management and planning procedure. This could be because these organizations differ in their working towards the completion of project as explained above.

Mehran University Research Journal of Engineering \& Technology, Volume 37, No. 1, January, 2018 [p-ISSN: 0254-7821, e-ISSN: 2413-7219] 
Effect of Organizational Structures and Types of Construction on Perceptions of Factors Contributing to Project Failure in Pakistan

TABLE 3. COMPARISON OF FUNCTIONAL AND PROJECT - BASED ORGANIZATIONS

\begin{tabular}{|c|c|c|}
\hline Factor & t-test Probability & Rank Correlation \\
\hline Inadequate project formulation & 0.46 & 0.86 \\
\hline Poor planning process for implementation & 0.29 & 0.86 \\
\hline Discrepant objectives and goals & 0.68 & 0.83 \\
\hline Changes in scope of work and location & 0.66 & 0.90 \\
\hline Inaccurate evaluation of project time/duration & 0.92 & 0.88 \\
\hline Lacking resources in term of financing and staff & 0.96 & 0.94 \\
\hline Poor procurement practices & 0.34 & 0.91 \\
\hline Inadequate financial methods & 0.92 & 0.90 \\
\hline Invalid budgeting process & 0.67 & 0.94 \\
\hline Enterprise management of budget resources & 0.64 & 0.96 \\
\hline Poor leadership & 0.52 & 0.86 \\
\hline Changes in Organizational priorities & 0.40 & 0.95 \\
\hline No change control process & 0.74 & 0.85 \\
\hline Meeting Client expectations & 0.06 & 0.82 \\
\hline Centralized proactive management initiatives to take on project risk & 0.67 & 0.88 \\
\hline Failure to adequately distinguish, document and track requirements & 0.51 & 0.91 \\
\hline Poor team management & 0.16 & 0.89 \\
\hline Unsound management decisions & 0.70 & 0.95 \\
\hline Impossible deadlines imposed on the project & 0.59 & 0.84 \\
\hline Ill-defined roles and responsibilities & 0.96 & 0.92 \\
\hline Inadequate coordination and communication & 0.32 & 0.92 \\
\hline Key project stakeholders Conflict & 0.36 & 0.89 \\
\hline Lack of End user input & 0.80 & 0.93 \\
\hline Undefined requirements & 0.67 & 0.93 \\
\hline
\end{tabular}

\section{CONCLUSION}

This study was dedicated towards finding out the perceptions regarding factors related to project failures in the construction industry of Pakistan. Moreover, it was also investigated if the perceptions of different construction sectors (building and infrastructure projects) and organizations (functional and project - based) differ from one another.

It was found that the factors related to project planning and management have higher ratings for both construction sectors and organizations, as shown by comparative analysis. Meeting client's requirements were found to have lower rating, which may be because of its dependence on other factors, rated by the respondents.

It was observed from the comparative analysis that factors related to organizational structure and practices have statistically higher difference in perceptions of building and infrastructure construction sectors. This indicates the fact that the organizational structure changes from one construction sector to another. Statistically higher difference in perception was also observed for project planning and team management factors for different types 
of organizational structure. This is understandable since these organizations work differently in the construction industry.

Moreover, it was also found that infrastructure projects are less sensitive to project duration and deadlines, which can be attributed to their longer durations. It was also observed that, meeting clients' requirements were rated higher by project-based organizations as compared to functional organizations. This difference was also found to be statistically more significant as compared to the other factors among these organizations. This points to the fact, project - based organizations are more focused on the clients' requirements in comparison with functional organizations.

On the basis of comparison done in this study, it can be concluded that organizational structures affect the perceptions of factors related to project team. On the other hand, the nature of construction has a more prominent effect on the perceptions of factors related to planning processes and mechanisms.

The factors which are found to be perceived differently between various construction sectors and organizations should be studied in more detail. Future research efforts are recommended to be more focused on the factors contributing to this difference in perception. Moreover, the applicability of this research to construction industries of other regions should also be investigated.

\section{ACKNOWLEDGEMENT}

Authors acknowledge the support provided by Mr. Ahsan Ali, conducting this research. Authors also acknowledge the support provided by NED University of Engineering \& Technology, Karachi, Pakistan, conducting this research.

\section{REFERENCES}

[1] Asaf, S., Hassnain, M. A., and Al-Zahrani S., "Causes of Contractors' Failure in Industrial Projects in Saudi Arabia”, Research Journal of Applied Sciences, Engineering and Technology, Volume 9, No. 3, pp. 158-164, 2015.

[2] Khahro, S.H., Memon, F.A., and Talpur, M.A.H., "Attribute Hierarchy of Conflicts in Construction Projects: A Case Study of Sindh”, Mehran University Research Journal of Engineering \& Technology, Volume 34, No. 4, 447-452, Jamshoro, October, 2015.

[3] Project Management Institute, "Guide to the Project Management Body of Knowledge: PMBOK Guide”, Pennsylvania Newtown Square: Project Management Institute, Inc, 2004.

[4] Schleifer, T.C., "Construction Contractor’s Survival Guide”, Wiley Inter Science, USA, 1990.

[5] Ogunlana, S.O., Promkuntong, K., and Vithool, J., "Construction Delays in a Fast Growing Economy: A Comparison of Thailand with Other Developing Economies”, International Journal of Project Management, Volume 14, No. 1, pp. 37-45, 1994.

[6] Russell, J.S., and Jaselskis, E.J., "Predicting Construction Contractor Failure Prior to Contract Award”, Journal of Construction Engineering and Management, Volume 11, No. 4, pp. 791-811, 1992.

[7] Kazaz, A., Ulubeyli, S., and Tuncbilekli, N.A., "Causes of Delays in Construction Projects in Turkey”, Journal of Civil Engineering and Management, Volume 18, No. 3, pp. 426-435, 2012.

[8] Jannadi, M.O., "Reasons for Construction Business Failure in Saudi Arabia”, Project Management Journal, Volume 28, No. 2, pp. 32-36, 2000.

[9] Arditi, D., Koksal, A., and Kale, S., "Business Failure in the Construction Industry”, Engineering Construction and Architecture Management, Volume 7, No. 2, pp. 120-132, 2000. 
[10] Davidson, R.A., and Maguire, M.G., "Ten Most Common Causes of Construction Contractor Failures”, Journal of Construction Accounting and Taxation, Volume 13, No. 1, pp. 35-37, 2003

[11] Kangari, R., "Business Failure in Construction Industry", Journal of Construction Engineering, Volume 114, No. 2, pp. 172-190, 1988.

[12] Sanvido, V., Grobler, F., Parfitt, K., Guvenis, M., and Coyle, M., "Critical Success Factors for Construction Projects”, Journal of Construction Engineering and Management, Volume 118, No. 1, pp. 94-111, 1992.

[13] Nguyen, D.L., Ogunlana, S.O., and Lan, T.X.D., “A Study on Project Success Factors in Large Construction Projects in Vietnam”, Engineering, Construction and Architectural Management, Volume 11, No. 6, pp. 404-413, 2004.

[14] Doloi, H., Sawhney, A., Iyer, K.C., and Rentala, S., “Analyzing Factors Affecting Delays in Indian Construction Projects”, International Journal of Project Management, Volume 30, No. 4, pp. 479-489,2012.

[15] Yong, C.Y., and Mustaffa, E.N., "Analysis of Factors Critical to Construction Project Success in Malaysia”, Engineering, Construction and Architectural Management, Volume 19, No. 5, pp. 543-556, 2012.

[16] Ye, S., and Tiong, R.L., "NPV-At-Risk Method in Infrastructure Project Investment Evaluation”, Journal of Construction Engineering and Management, Volume 126, No. 3, pp. 227-233, 2000.

[17] Li, T.H., Ng, S.T., and Skitmore, M., "Conflict or Consensus: An Investigation of Stakeholder Concerns During The Participation Process of Major Infrastructure and Construction Projects in Hong Kong”, Habitat International, Volume 36, No. 2, pp. 333-342, 2012.

[18] Zhang, X., “Critical Success Factors for Public-Private Partnerships in Infrastructure Development”, Journal of Construction Engineering and Management, Volume 131, No. 1, pp. 3-14, 2005.
[19] Chou, J.S., Tserng, H.P., Lin, C., and Yeh, C.P., "Critical Factors and Risk Allocation for PPP Policy: Comparison Between HSR and General Infrastructure Projects”, Transport Policy, Volume 22, pp. 36-48, 2012.

Li, B., Akintoye, A., Edwards, P.J., and Hardcastle, C., “Critical Success Factors for PPP/PFI Projects in the UK Construction Industry”, Construction Management and Economics, Volume 23, No. 5, pp. 459-471, 2005.

[21] Hwang, B.G., Zhao, X., and Gay, M.J.S., "Public Private Partnership Projects in Singapore: Factors, Critical Risks and Preferred Risk Allocation from the Perspective of Contractors”, International Journal of Project Management, Volume 31, No. 3, pp. 424-433, 2013.

Hyväri, I., “Project Management Effectiveness in Project-Oriented Business Organizations”, International Journal of Project Management, Volume 24, No. 3, pp. 216-225, 2006.

Hyvari, I., "Success of Projects in Different Organizational Conditions”, Project Management Journal, Volume 37, No. 4, pp. 31-41, 2006.

Lechler, T.G., and Dvir, D., “An Alternative Taxonomy of Project Management Structures: Linking Project Management Structures and Project Success”, IEEE Transactions on Engineering Management, Volume 57, No. 2, pp. 198-210, 2010.

Joslin, R., and Müller, R., "Relationships between A Project Management Methodology and Project Success in Different Project Governance Contexts”, International Journal of Project Management, Volume 33, No. 6, pp. 1377-1392, 2015.

Khan, R.A., Gazder, U., and Ali, A., "Review of Financial Practices in Construction Industry of Pakistan”, Proceedings of $7^{\text {th }}$ International Civil Engineering Congress, pp. 22-28, 2015, (Available at http:// i e p k a rachi.org. p k/D o w n load s / I C E C 2015\%20_\%20Full\%20). 
[27] Shaikh, P., Khahro, S.H., and Memon, A.A., “Adoption of Value Engineering: An Attribute Study for Construction Industry of Pakistan”, Mehran University Research Journal of Engineering \& Technology, Volume 34, No. 4, pp. 453-460, Jamshoro, Pakistan, October, 2015.

[28] Devore, J., "Probability and Statistics for Engineering and the Sciences”, Cengage Learning, San Luis Obispo, California, USA, 2015.
Zar, J.H., "Significance Testing of The Spearman Rank Correlation Coefficient”, Journal of the American Statistical Association, Volume 67, No. 339, pp. 578-580, 1972.

[30] Rober, C., Ford, W., and Randolph, A., "Cross-Functional Structures: A Review and Integration of Matrix Organization and Project Management”, Journal of Management, Volume 18, No. 2, 1992. 